\title{
KEEFEKTIFA MODEL PEMBELAJARAN COURSE REVIEW HORAY BERBANTUAN POWER POINT TERHADAP KEPERCAYAAN DIRI DAN PRESTASI BELAJAR
}

\author{
Siti Eliyah ${ }^{1)}$, Isnani $^{2)}$, Wikan Budi Utami ${ }^{3)}$ \\ ${ }^{1), 2,3))}$ Program Studi Pendidikan Matematika Universitas Pancasakti Tegal \\ Eeliyah4@gmail.com
}

\begin{abstract}
Abstrak
Tujuan penelitian ini untuk mengetahui: (1)kepercayaan diri siswa yang diajar menggunakan model CRH lebih baik daripada model Konvensional, (2)prestasi belajar siswa yang diajar menggunakan model $\mathrm{CRH}$ lebih baik daripada model Konvensional, (3)ada perbedaan kepercayaan diri dan prestasi belajar antara siswa yang diajar menggunakan model CRH dengan model Konvensional, (4)kepercayaan diri dan prestasi belajar siswa yang diajar menggunakan model CRH lebih baik daripada model Konvensional. Penelitian ini merupakan penelitian eksperimen dengan desain Multivariat Post Test dengan Dua Kelompok Random. Populasi dalam penelitian ini adalah siswa kelas VIII SMP Negeri 4 Tegal Tahun Pelajaran 2017/2018, teknik pengambilan sampel dalam penelitian ini menggunakan Cluster random Sampling, diperoleh 95 siswa sebagai sampel. Teknik pengumpulan data yang digunakan yaitu dokumentasi, Angket dan Tes Prestasi. Teknik analisis data yang digunakan adalah Uji t satu pihak kanan, Uji Manova dan Uji Hotelling. Hasil penelitian menunjukan bahwa: (1)kepercayaan diri siswa yang diajar menggunakan model CRH lebih baik daripada model Konvensional, (2)prestasi belajar siswa yang diajar menggunakan model CRH lebih baik daripada model Konvensional, (3)ada perbedaan kepercayaan diri dan prestasi belajar antara siswa yang diajar menggunakan model CRH dengan model Konvensional, (4)kepercayaan diri dan prestasi belajar siswa yang diajar menggunakan model CRH lebih baik daripada model Konvensional.
\end{abstract}

Kata Kunci : Course Review Horay (CRH), Keefektifan, Kepercayaan Diri, Prestasi Belajar

\begin{abstract}
The purpose of this study is to describe: (1) the confidence of students taught using the CRH model is better than conventional models, (2) the learning achievement of students taught using the CRH model is better than conventional models, (3) there are differences in confidence and learning achievement between students who are taught using the CRH model with Conventional models, (4) the confidence and learning achievement of students who are taught using the $\mathrm{CRH}$ model are better than conventional models. The population used is the eighth grade students of State Junior High School 4 Tegal 2017/2018 Academic Year. The results showed that: (1) the confidence of students who were taught using the CRH model was better than conventional models, (2) the learning achievement of students taught using the CRH model was better than conventional models, (3) there were differences in confidence and learning achievement between students taught using the CRH model with Conventional models, (4) the confidence and learning achievement of students who are taught using the CRH model are better than conventional models.
\end{abstract}

Keywords: Course Review Horay (CRH), Effectiveness, Confidence, Learning Achievement 


\section{PENDAHULUAN}

Pendidikan memiliki beberapa jenjang antara lain pendidikan dasar, pendidikan menengah, dan pendidikan tinggi. Setiap pendidikan terutama pada jenjang Sekolah Menengah Pertama (SMP) terdapat satu mata pelajaran yang sangat penting yaitu matematika.

Hasil wawancara dengan salah satu guru matematika kelas VIII di SMP Negeri 4 Tegal, menjelaskan bahwa proses pembelajaran yang biasa digunakan adalah metode ceramah, berkelompok 2 sampai 3 orang, serta sebagai evaluasi siswa hanya diberi penugasan. Beliau juga menyatakan bahwa banyak siswa yang belum siap untuk mengikuti pembelajaran matematika. Ketika siswa ditunjuk untuk mengerjakan soal, sebagian siswa tidak berani untuk menyelesaikan soal yang diberikan guru dengan alasan takut jika jawaban yang telah dikerjakan salah. Pernyataan ini didukung oleh pendapat dari Yulianto \& Nashori, (2006:58) yang menyatakan bahwa kepercayaan diri merupakan suatu sikap atau perasaan yakin akan kemampuan diri sendiri sehingga orang yang bersangkutan tidak terlalu cemas dalam tindakan-tindakannya, dapat merasa bebas melakukan hal yang disukainya dan bertanggung jawab atas perbuatannya, hangat dan sopan dalam berinteraksi dengan orang dan memiliki dorongan untuk berprestasi. Berdasarkan pernyataan diatas dapat disimpulkan bahwa siswa masih kurang percaya diri dengan kemampuan mereka sehingga mengakibatkan prestasi belajar matematika masih rendah.

Beliau juga menyampaikan bahwa prestasi belajar siswa ditahun lalu masih rendah, terutama pada materi bangun ruang sisi datar kubus dan balok. Pernyataan ini juga diperkuat dengan nilai ulangan harian matematika siswa kelas VIII di SMP N 4 Tegal pada materi bangun ruang kubus dan balok tahun 2016/2017 yang masih rendah.

Berkaitan dengan masalah tersebut agar tidak berkelanjutan, guru dalam pembelajaran dikelas perlu memilih model pembelajaran yang efektif yaitu dengan pembelajaran dalam suasana yang menyenangkan yaitu dengan cara bermain sambil belajar mengenai suatu konsep. Salah satu model tersebut adalah Course Review Horay (CRH). Model pembelajaran ini dapat menciptakan suasana kelas menjadi meriah dan dapat membantu siswa untuk memahami konsep dengan baik melalui diskusi kelompok.

Penggunaan media pembelajaran sangat berpengaruh terhadap siswa, karena dengan media pembelajaran siswa akan lebih memahami ketika guru sedang memberikan penjelasan, dan dengan media pembelajaran juga siswa tidak akan bosan karena hanya berfokus pada satu tatapan yaitu papan tulis Sundayana (2016). Salah satu media 
pembelajaran yang dapat digunakan adalah komputer atau laptop. Komputer atau laptop dapat digunakan sebagai alat bantu dalam menyiapkan bahan ajar dalam proses pembelajaran yang efektif. Komputer atau laptop memiliki banyak software yang dapat membantu dalam proses pembelajaran. Software yang digunakan dalam media pembelajaran kali ini adalah microsoft power point. Mustikasari, Isnani \& Susongko (20017), mengemukakan bahwa media microsoft power point dapat meningkatkan prestasi belajar matematika siswa. Dalam penelitian ini media yang digunakan adalah microsoft power point yang diberi sentuhan Geogerbra agar siswa dapat memahami secara kongkrit (nyata), siswa dapat memahami materi bangun ruang sisi datar kubus dan balok secara mendalam. Diharapkan dengan adanya bantuan media ini dapat memberikan kemudahan bagi siswa untuk mempelajari matematika, dengan begitu siswa akan suka dan tidak merasa bosan untuk mengikuti pembelajaran matematika, sehingga akan timbul percaya diri dalam menyelesaikan permasalahan soal matematika tersebut. Dengan adanya kepercayaan diri pada siswa dalam belajar kemungkinan besar prestasi belajar yang dicapai akan memuaskan.

Berdasarkan penelitian sebelumnya oleh Amaliyah (2017), Sari (2017), Amelia \& Siahaan (2016), Auliya (2013) didapatkan hasil bahwa ada peningkatan prestasi belajar matematika siswa yang diajarkan dengan model pembelajaran kooperatif tipe Course Review Horay. Dari hasil penelitian tersebut, kemudian dikaji dengan mengangkat sebuah judul Keefektifan Model Pembelajaran Kooperatif Tipe Course Review Horay Berbantuan Microsoft Power Point terhadap Kepercayaan Diri dan Prestasi Belajar Matematika Siswa. (Suatu Penelitian Eksperimen pada Siswa Kelas VIII Semester Genap Materi Pokok Bangun Ruang di SMP Negeri 4 Tegal Tahun Ajaran 2017/2018).

Tujuan penelitian ini yaitu nilainya Mendeskripsikan apakah kepercayaan diri siswa yang diajarkan menggunakan model pembelajaran kooperatif tipe Course Review Horay berbantuan microsoft power point lebih baik dari siswa yang diajar menggunakan model pembelajaran konvensional. Mendeskripsikan apakah prestasi belajar siswa yang diajar menggunakan model pembelajaran kooperatif tipe Course Review Horay berbantuan microsoft power point lebih baik dari siswa yang diajar menggunakan model pembelajaran konvesional. Mendeskripsikan apakah ada perbedaan antara kepercayaan diri dan prestasi belajar siswa yang diajarkan menggunakan model pembelajaran kooperatif Course Review Horay berbantuan microsoft power point dengan siswa yang diajar menggunkan model pembelajaran konvensional. Mendeskripsikan apakah kepercayaan diri dan prestasi belajar matematika siswa yang diajar menggunakan model pembelajaran kooperatif tipe Course 
Review Horay berbantuan microsoft power point lebih baik dari siswa yang diajar menggunakan model pembelajaran konvensional.

\section{LANDASAN/KAJIAN TEORI}

\section{Course Review Horay (CRH)}

Menurut Aksiwi \& Sagoro, (2014:38) Model pembelajaran kooperatif Course Review Horay adalah model pembelajaran yang beorientasi pada peningkatan aktivitas dan hasil belajar siswa. Pada model ini juga merupakan model dengan pengujian pemahaman siswa menggunakan kotak yang berisi nomor untuk menuliskan jawabannya. Siswa yang lebih dulu mendapat tanda atau jawaban benar langsung berteriak "horay" atau yel-yel yang telah dipersiapkan sebelumnya.

$$
\text { Berikut langkah-langkah }
$$

model pembelajaran Course Review Horay Aksiwi \& Sagoro, (2014:38):

1) Guru menyampaikan kompetensi yang ingin dicapai

2) Guru

mendemonstrasikan/menyajikan materi

3) Memberikan kesempatan siswa untuk tanya jawab.

4) Untuk menguji pemahaman, siswa disuruh membuat kotak sesuai dengan kebutuhan dan tiap kotak diisi angka sesuai dengan selera masing-masing.

5) Guru membacakan soal secara acak dan siswa menulis jawaban di dalam kotak yang nomornya disebutkan guru dan langsung didiskusikan. Kalau benar diisi tana

$(\sqrt{ })$ dan salah diisi tanda silang $(X)$.

6) Siswa yang sudah mendapat tanda $(\sqrt{ })$ vertikal atau horisontal atau diagonal harus berteriak horay atau yel-yel lainnya.

7) Nilai siswa dihitung dari jawaban benar jumlah horay yang diperoleh.

Kelebihan dan kekurangan model pembelajaran Course Review Horay Aksiwi \& Sagoro, (2014:38):

1) Kelebihan

a) Menarik sehingga mendorong siswa terlibat didalamnya.

b) Tidak monoton karena diselingi sedikit hiburan sehingga suasana tidak menegangkan.

c) Siswa lebih semangat belajar.

d) Melatih kerjasama.

2) Kekurangan

a) Adanya peluang untuk curang

b) Siswa aktif dan pasif nilainya disamakan.

\section{Keefektifan}

Menurut Trianto, (2010:20-21) keefektifan adalah suatu usaha yang dilakukan guru guna memperoleh hasil desuai dengan yang diinginkannya. Menurut Sinambela, (2017:78) pembelajaran dikatakan efektif apabila mencapai sasaran yang didinginkan, baik dari segi tujuan pembelajaran dan prestasi siswa yang maksimal, sehingga yang merupakan indikator keefektifan berupa: 1)ketercapaian ketuntasan belajar; 2)ketercapaian efektivitas siswa; 3)ketercapainya evektivitas kemempuan guru mengelola pembelajaran; serta 4)respon siswa terhadap pembelajaran yang posistif. 
Jadi keefektifan yang dimaksud dalam penelitian ini adalah tingkat keberhasilan yang dapat dicapai dari suatu usaha atau penerapan model $\mathrm{CRH}$ guna mencapai tujuan kepercayaan diri dan prestasi belajar matematika siswa yang lebih baik. Keberhasilan suatu usaha setelah dilakukan suatu proses mengajar, dalam hal ini untuk mencapai keefektifan dalam pembelajaran yaitu menguasai bahan pelajaran, cinta kepada yang diajarkan atau yang akan diajarkan, variasi metode dalam pembelajaran, memberikan pengetahuan yang aktual, berani memberikan pujian, dan mampu menimbulkan semangat belajar yang individual.

\section{Kepercayaan Diri}

Menurut Kushartanti, (2009:41). Kepercayaan diri adalah suatu bagian dari kehidupan yang unik dan berharga. Ada orang yang menganggap diri mereka penuh kepercayaan diri tiba tiba merasa kepercayaan diri mereka tak sebesar apa yang selama ini mereka duga, sehingga mereka kurang percaya diri dimana baginya dunia terasa sebagai tempat yang tidak aman dan menyulitkan. Dengan kepercayaan diri yang dimiliki diharapkan ketika menyelesaikan tugas atau ujian di sekolah, siswa akan percaya pada kemampuan yang dimiliki sehingga perilaku menyontek dapat dihindari. Dengan kepercayaan diri yang tinggi maka akan membiasakan siswa untuk bersikap positif terhadap kemampuannya dan tidak mudah terpengaruh oleh orang lain.
Menurut Lestari \& Yudhanegara (2017: 95) Kepercayaan diri (Self-Confidence) adalah suatu sikap yakin akan kemampuan diri sendiri dan memandang diri sendiri sebagai pribadi yang utuh dengan mengacu pada konsep diri. Indikator kepercayaan diri (self-confidence) adalah:

a. Percaya pada kemampuan diri sendiri

b. Bertindak mandiri dalam mengambil keputusan

c. Memiliki konsep diri yang positif

d. Berani mengemukakan pendapat

Dari beberara pendapat diatas
dapat disimpulakan bahwa
Kepercayaan didik dalam proses
pembelajaran matematika sangat
dibutuhkan, karena ketika kepercayaan
diri muncul maka rasa semangat untuk
mengikuti pembelajaran pun akan
meningkat sehingga membuat prestasi
belajar lebih bagus.
Prestasi Belajar

Menurut Hamdani, (2011:138) Prestasi belajar adalah hasil yang diperoleh berupa kesan-kesan yang mengakibatkan dalam diri individu, yaitu perubahan tingkah laku. Dengan demikian, prestasi belajar adalah hasil yang diperoleh berupa kesan-kesan yang mengakibatkan perubahan pada diri individu sebagai hasil dari aktivitas dalam belajar.

Menurut Tu'u, (2004:75) prestasi belajar adalah penguasaan pengetahuan atau ketrampilan yang dikembangkan oleh mata pelajaran lazimnya diberikan nilai tes yang diberikan oleh guru. 
Dari pengertian diatas dapat dapat diartikan prestasi belajar adalah hasil dari proses atau aktivitas sehingga menghasilkan sebuah perubahan dalam individu yaitu berupa nilai.

\section{METODOLOGI}

\section{Jenis Penelitian}

Jenis penelitian ini adalah penelitian eksperimen dengan desain penelitian Multivariat Post Test dengan Dua Kelompok Random.

\section{Waktu dan Tempat Penelitian}

Penelitian ini dilaksanakan di SMP N 4 Tegal. Waktu yang digunakan peneliti untuk mengadakan penelitian yaitu pada semester genap tahun pelajaran 2017/2018.

\section{Subjek Penelitian}

Populasi yang digunakan adalah siswa kelas VIII SMP N 4 Tegal semester genap tahun pelajaran 2017/2018. Yang terdiri dari 190 siswa. Sampel dalam penelitian ini berjumlah 95 siswa. Teknik pengambilan sampel dalam penelitian ini menggunakan Cluster random Sampling.

\section{Data, Intrumen, dan Teknik Pengumpulan Data}

Intrumen pada penelitian ini ialah dokumentasi, Angket dan Tes Prestasi.

\section{Teknik Analisis Data}

Tabel 1.

Hasil Analisis Data Kepercayaan Diri dengan Uji t Satu Pihak Kanan

\begin{tabular}{ccc}
\hline $\boldsymbol{t}_{\text {hitung }}$ & $\boldsymbol{t}_{\text {tabel }}$ & Kesimpulan \\
\hline 3,255 & 1,671 & $3,255>1,671$ \\
\hline
\end{tabular}

Berdasarkan Tabel diatas menunjukkan bahwa thitung $=3,255$ kemudian hasil tersebut
Teknik analisis data yang digunakan adalah Uji $\mathrm{t}$ satu pihak kanan, Uji Manova dan Uji Hotelling untuk setelah penelitian.

\section{HASIL PENELITIAN DAN PEMBAHASAN}

Sebelum menghitung hipotesis terlebih dahulu dilakukan yaitu menghitung uji normalitas dan homogenitas univariat yaitu dilakukan sebagai syarat dalam perhitungan hipotesis yaitu uji $\mathrm{t}$ satu pihak kanan, karena data tersebut berdistribusi normal dan homogen univariat maka dapat dilakukan Uji $t$ Satu Pihak Kanan. Pada uji Uji Manova dimana syarat uji manova data harus berdistribusi normal dan homogen. Dalam penelitian ini uji normalitas dan homogenitas yang digunakan adalah uji normalitas dan homogenitas multivariat. Karena data tersebut berdistribusi normalitas dan homogenitas multivariate maka dapat dilakukan Uji Manova.

\section{Hasil Analisis Kepercayaan Diri dengan Uji t Satu Pihak Kanan}

Untuk menentukan apakah model pembelajaran kooperatif tipe Course Review Horay berbantuan microsoft power point lebih baik daripada model pembelajaran konvensional terhadap kepercayaan diri siswa maka dilakukan uji $\mathrm{t}$ satu pihak kanan. Adapun ringkasan perhitungan sebagai berikut: dan $\alpha=5 \%$, ttabel sebesar 1,671 . 
Dan karena thitung > ttabel maka model pembelajaran kooperatif tipe Course Review Horay berbantuan microsoft power point lebih baik daripada model pembelajaran konvensional Terhadap kepercayaan diri siswa.

\section{Hasil Analisis Prestasi dengan Uji t Satu Pihak Kanan}

Untuk menentukan apakah model pembelajaran kooperatif tipe Course Review Horay berbantuan microsoft power point lebih baik daripada model pembelajaran konvensional terhadap prestasi belajar siswa maka dilakukan uji $\mathrm{t}$ satu pihak kanan. Adapun ringkasan perhitungan sebagai berikut:

Tabel 2.

Hasil Analisis Data Prestasi dengan Uji t Satu Pihak Kanan

\begin{tabular}{ccc}
\hline $\boldsymbol{t}_{\text {hitung }}$ & $\boldsymbol{t}_{\text {tabel }}$ & Kesimpulan \\
\hline 2,171 & 1,671 & $2,171>1,671$ \\
\hline
\end{tabular}

Berdasarkan Tabel diatas menunjukkan bahwa $t_{\text {hitung }}=2,171$ kemudian hasil tersebut dikonsultasikan dengan nilai daftar distribusi $\mathrm{t}$ dengan $\mathrm{dk}=\left(\mathrm{n}_{1}+\mathrm{n}_{2}-2\right)$ dan $\alpha=5 \%, t_{\text {tabel }}$ sebesar 1,671. Dan karena $t_{\text {hitung }}>t_{\text {tabel }}$ maka model pembelajaran kooperatif tipe Course Review Horay berbantuan microsoft power point lebih baik daripada model pembelajaran konvensional Terhadap prestasi belajar siswa.

\section{Hasil Analisis Uji One-Way MANOVA}

Untuk mengetahui ada tidaknya perbedaan kepercayaan diri dan prestasi belajar matematika siswa yang diajar menggunakan model pembelajaran kooperatif tipe Course Review Horay berbantuan microsoft power point dengan siswa yang diajar menggunakan model pembelajaran konvensional, menggunaan uji One Way Manova. Adapun ringkasan perhitungannya sebagai berikut

Tabel 3.

Hasil Analisis Data Kepercayaan Diri dan Prestasi Belajar Matematika Siswa dengan uji One -Way Manova

\begin{tabular}{cccccc}
\hline No. & $\begin{array}{c}\text { Sumber } \\
\text { keragaman }\end{array}$ & $\boldsymbol{D B}$ & JK dan JHK & $\lambda_{\text {hitung }}$ & $\begin{array}{c}\boldsymbol{\lambda}_{\text {tabel }} \\
(\boldsymbol{\alpha}=\mathbf{5 \%})\end{array}$ \\
\cline { 1 - 3 } 1 & Perlakuan (H) & 1 & $H=\left[\begin{array}{cc}2256,06 & 1357,26 \\
1357,26 & 816,53\end{array}\right]$ & & \\
\cline { 1 - 2 } 2 & Galat (E) & 60 & $H=\left[\begin{array}{cc}12775,94 & 2952,74 \\
2952,74 & 10390,32\end{array}\right]$ & 0,827 & 0,903 \\
\cline { 1 - 2 } 3 & Total (T) & 61 & $H=\left[\begin{array}{cc}15032 & 4310 \\
4310 & 11206,85\end{array}\right]$ & & \\
\hline
\end{tabular}

Berdasarkan hasil tabel diatas menunjukan bahwa $\lambda_{\text {hitung }}=0,82$ hasil tersebut kemudian dikonsultasikan dengan $\lambda$ tabel dengan $\mathrm{p}=$ banyaknya 
variabel respon $=2, V_{H}=$ derajat bebas perlakuan $=1$, dan $V_{E}=$ derajat bebas galat $=60$ serta taraf signifikansi $5 \%$ maka diperoleh $\lambda_{\text {tabel }}=0,903$. $\lambda_{\text {hitung }}<$ $\lambda_{\text {tabel }}$ maka Ho ditolak artinya ada perbedaan kepercayaan diri dan prestasi belajar siswa yang diajar menggunakan Model Course Review Horay berbantuan microsoft power point dengan model pembelajaran konvensional

\section{Hasil Analisis Uji $\tau^{2}$-Hotelling}

Tabel 4.

\begin{tabular}{cccc}
\multicolumn{4}{c}{ Hasil Analisis Uji $\tau^{2}$-Hotelling } \\
\hline No. & $\boldsymbol{\tau}_{\text {hitung }}^{2}$ & $\begin{array}{c}\boldsymbol{\tau}^{2}{ }_{\text {tabel }} \\
(\boldsymbol{\alpha}=\mathbf{5 \% )}\end{array}$ & Kesimpulan \\
\hline 1 & 12,926 & 6,413 & $12,926>6,413$
\end{tabular}

Berdasarkan perhitungan uji $\tau$ '-Hotelling menunjukkan bahwa $\tau_{\text {hitung }}^{2}=12,926$. Hasil tersebut kemudian konsultasikan dengan $\tau^{2}$ tabel, dengan $\quad \mathrm{p}$ (banyaknya variabel respon $)=2, \mathrm{v}_{\mathrm{H}}(\mathrm{db}$ perlakuan $)=1 \mathrm{dan}$ $\mathrm{v}_{\mathrm{E}}(\mathrm{db}$ galat $)=60$ serta taraf signifikansi 5\%, maka diperoleh $\tau_{\text {tabel }}^{2}$ $=6,413$. Karena $\quad \tau_{\text {hitung }}^{2}>\tau_{\text {tabel }}^{2}$, maka Ho ditolak yang artinya pembelajaran Course Review Horay berbantuan microsoft power point lebih baik dibandingkan dengan model pembelajaran Konvensional terhadap kepercayaan diri dan prestasi belajar siswa.

Hasil penelitian ini sejalan dengam Amaliyah (2017), Sari (2017), Amelia \& Siahaan (2016), Auliya (2013) yang menyatakan bahwa ada peningkatan prestasi belajar matematika siswa yang diajarkan
Untuk mengetahui kepercayaan diri dan prestasi belajar matematika siswa yang diajar menggunakan model pembelajaran kooperatif tipe Course Review Horay berbantuan microsoft power point lebih baik dengan siswa yang diajar menggunakan model pembelajaran konvensional, menggunaan uji. $\tau^{2}$-Hotelling Adapun ringkasan perhitungannya sebagai berikut: 
Hal ini sejalan dengan hasil penelitian Mustikasari, Isnani \& Susongko (20017), yang mengemukakan bahwa media microsoft power point dapat meningkatkan prestasi belajar matematika siswa.

\section{SIMPULAN DAN SARAN}

\section{Kesimpulan}

Berdasarkan hasil analisis yang telah diperoleh, maka dapat diambil kesimpulan bahwa:

(1) Kepercayaan diri siswa yang diajar menggunakan model pembelajaran Course Review Horay berbantuan microsoft power point lebih baik daripada siswa yang diajar menggunakan model pembelajaran Konvensional.

(2) Prestasi belajar matematika siswa yang diajar menggunakan model pembelajaran Course Review Horay berbantuan microsoft power point lebih baik daripada yang diajar menggunakan model pembelajaran Konvensional.

(3) Ada perbedaan kepercayaan diri dan prestasi belajar matematika siswa yang diajar menggunakan model pembelajaran Course Review Horay berbantuan microsoft power point dengan siswa yang diajar menggunakan model pembelajaran Konvensional.

(4) Kepercayaan diri dan prestasi belajar matematika siswa yang diajar menggunakan model pembelajaran Course Review Horay berbantuan microsoft power point lebih baik daripada yang diajar menggunakan model pembelajaran Konvensional.

Saran

Berdasarkan hasil penelitian, beberapa saran yang dapat di sampaikan antara lain:

(1) Model pembelajaran kooperatif tipe Course Review Horay dapat dijadikan sebagai salah satu alternatif model pembelajaran yang dapat digunakan dalam pembelajaran matematika untuk meningkatkan kepercayaan diri siswa dalam mengikuti pembelajaran matematika.

(2) Hasil penelitian ini dapat dijadikan sebagai referensi dalam penelitian yang sejenis dengan variabelvariabel yang berbeda. Selain itu, penelitian ini menerapkan model pembelajaran Course Review Horay berbantuan microsoft power point yang tidak hanya diterapkan pada materi bangu ruang sisi datar kubus dan balok, tetapi juga diterapkan pada materi lain.

\section{DAFTAR PUSTAKA}

Aksiwi, R., D. \& Sagoro, E., M. (2014). Implementasi Metode Pembelajaran Course Review Horay untuk Meningkatkan Aktivitas dan hasil Belajar Jurnal Penyesuaian. Juenal Pendidikan Akuntansi Indonesia. Vol. 12 No. 1, 3647.

Amaliyah, T. (2017). Keefektifan Model Pembelajaran Course 
Review Horay dengan Pendekatan Ketrampilan

Proses Terhadap Minat dan

Prestasi Belajar Matematika

Pada Materi Lingkaran.

Skripsi : Universitas

Pancasakti Tegal.

Amelia, F., \& Siahaan, F. H. (2016).

Perbandingan Model

Pembelajaran Kooperatif Tipe

Course Review Horay dengan

Time Token Arends terhadap

Hasil Belajar Matematika

Siswa Kelas VIII di SMP

Lakssaman Batam Tahun

Pelajaran 2014 /

2015. PYTHAGORAS: Jurnal

Program Studi Pendidikan

Matematika, 4(2).

Auliya, R. N. (2013). Pengaruh Model

Pembelajaran Kooperatif Tipe

CRH (Course, Review, Hurray)

Terhadap

Kemampuan

Pemahaman Matematis dan

Kecemasan Matematika Siswa

SMP (Doctoral dissertation,

Universitas Pendidikan

Indonesia).

Hamdani. (2011). Strategi Belajar

Mengajar. Bandung : Pustaka

Setia

Kushartanti, A. (2009). Perilaku

Menyontek ditinjau dari

Kepercayaan Diri. Indigenous,

Jurnal Ilmiah Berkala

Psikologi. Vol. 11, No. 2, 38-

46.

Lestari, K.E dan Yudhanegara M.R. (2017). Penelitian Pendidikan Matematika. Bandung: PT Refika Aditama.
Mustikasari, M., Isnani, I., \& Susongko, P. (2017). Keefektifan Model Pembelajaran Talking Stick Berbantu Media Microsoft Power Point Terhadap Prestasi Belajar Matematika Ditinjau Dari Kemampuan Numerikmateri Pokok Statistika. JPMP, 1(1).

Sari, D. K. (2017). Efektivitas Model Pembelajaran Course Review Horay Berbantuan Handout Terhadap Prestasi Belajar Peserta Didik Kelas X Ma Ribatul Muta'allimin Kota Pekalongan. Delta: Jurnal Ilmiah Pendidikan Matematika, 3(1), 15-24.

Sinambela, P. N. (2017). FaktorFaktor Penentu Keefektifan Pembelajaran dalam Model Pembelajaran Berdasarkan Masalah (Problem Based Instruction). Generasi

Kampus, 1(2).

Sundayana, R. (2016). Media dan Alat Peraga dalam Pembelajaran Matematika. Bandung. Alfabeta

Trianto, (2009). Mendesain Model Pembelajan Inovatif Progresif. Kencana.

Tu'u, T. (2004). Peran Disiplin pada Perilaku dan Prestasi Siswa. Jakarta: PT Gramedia Widia Sarana Indonesia.

Yulianto, F., \& Nashori, F. (2006). Kepercayaan diri dan prestasi atlet tae kwon do daerah istimewa Yogyakarta. Jurnal Psikologi, 3(1), 55-62 